Bogustaw Wyderka

Uniwersytet Opolski

Instytut Polonistyki i Kulturoznawstwa

Katedra Języka Polskiego

\title{
PRZYCZYNEK DO OPISU ROZWOJU ŚLĄSKIEGO SLOWNICTWA GWAROWEGO
}

W charakterystykach słownictwa dialektu śląskiego zwraca się uwagę przede wszystkim na takie właściwości, które związane są z dziejami politycznymi i kulturowymi Śląska, a więc uwydatnia się więź z leksyką języka polskiego, wskazuje na obecność staropolskich archaizmów, dość powierzchownie omawia się wpływy języka niemieckiego i czeskiego. Odczuwalny jest natomiast brak analiz etymologicznych i porównawczych, które szczegółowo pokazywałyby powiązania śląskiej leksyki gwarowej ze słownictwem dialektów sąsiednich, czy też z ogólnosłowiańskimi procesami rozwoju leksyki. Wnioski z takich analiz mogą wprowadzić wiele korekt do stereotypowych charakterystyk śląskiej leksyki i ujawnić uwikłane ścieżki jej rozwoju. Ten ogólny postulat potwierdza kilka niżej prezentowanych analiz.

Wśród śląskich archaizmów uwagę zwraca niewielka grupka wyrazów pochodzących od psł. *blkati, perf. blknąti (> pol. betkać, betknać) 'o odgłosie płonącego ognia, wrzącej wody', także 'niewyraźnie mówić, bełkotać, gadać' [SłPsł I, s. 282]. Drugie z odnotowanych znaczeń jest według Andrzeja Bańkowskiego wtórne [2000, s. 40] - ta sugestia mniej nas tu interesuje. Formy bełkać nie zanotowano w leksykonach polszczyzny. Natomiast w gwarach śląskich zachowała się perfektywna postać tego czasownika, mianowicie betknać, betknyć. Notuje ją też [SłStp], zob. betknąć, wzbetknać, oraz [Linde] w źródle XVIII-wiecznym. Użycia o pierwotnym znaczeniu 'buchnać płomieniem' notowano tylko na Śląsku Cieszyńskim, użycia o znaczeniu 'powiedzieć coś niewyraźnie, mruknąć pod nosem' w gwarach środkowego i północnego Śląska [SGŚ]. Tak więc pierwotne znaczenie 
kontynuuje tylko południe Śląska. Co się tyczy innych gwar polskich, to oprócz Śląska wyraz betknać odnotowano jedynie w gwarach Sądecczyzny (Mszana Dolna i Górna), ale w znaczeniach już zmodyfikowanych w stosunku do pierwotnego, tj. 'niepotrzebnie coś powiedzieć, wygadać się' oraz 'krzyknąć' [SGP].

Oprócz omówionego czasownika betknać, na Śląsku pojawiają się jego derywaty betk i betko. Pierwszy z nich, betk, o pierwotnym znaczeniu 'topiel wodna, głębia, wir' ma w zasadzie zasięg ogólnogwarowy, lecz na Śląsku wyraz pojawia się peryferyjnie na południu (Koniaków pow. cieszyński) i na północy (Krzywizna pow. kluczborski), co sugeruje szeroki pierwotnie zasięg wyrazu. Natomiast forma betko wystapiła w zaolziańskiej gwarze Gródka (pow. mistecki) w znaczeniu 'głębokie miejsce w rzece lub stawie, głębia; wir' oraz 'stroma skała nad urwistym brzegiem rzeki; urwisko'. Leksem betko, niewątpliwie pierwotne zdrobnienie od beto 'głębokie miejsce w rzece; staw', w większej mierze rozpowszechniony jest w gwarach małopolskiego Pogórza, gdzie notujemy też beło [SGP]. Współczesna geografia wyrazu sugeruje, że zaolziańskie bełko jest refleksem małopolskiego zasięgu leksemu.

W rodzinie wyrazów pochodnych od pierwotnego *betkać wyłącznie śląskim dialektyzmem jest bełkocić (bełkoca $(m)$ - betkocisz - betkocil) w znaczeniu 'mówić niewyraźnie i niezrozumiale'. Występuje na znacznym obszarze południowego Śląska (pow. wodzisławski, raciborski, rybnicki i gliwicki) obok derywatów wspólnych z polszczyzną ogólną: betkotać, bełkotanie, betkot.

Synonimami wyrazu pobożny są na Śląsku: bogobojny, bogabojny i bogomyśl$n y$. Pierwszy z nich nie budzi szczególnej uwagi ani pod względem semantycznym, ani etymologicznym, nie różni się bowiem od postaci ogólnopolskiej i notowany jest w różnych okolicach Śląska [zob. SGŚ]. Natomiast uwagę zwraca forma bogabojny, którą zanotowano w gwarach Śląska środkowego: Bytom (Rozbark), Tarnowskie Góry (Strzybnica), Żędowice pow. strzelecki, oraz w najdalej na zachód wysuniętych gwarach śląskich okolic Niemodlina. Wyraz w tej postaci pojawia się również w innych gwarach polskich (małopolskich, wielkopolskich, kujawskich), lecz tam wyjątkowo. Natomiast na Śląsku zapisano go kilkakrotnie, przyjąć zatem możemy, że tu ma mocne zakotwiczenie. Czy śląskie bogabojny jest refleksem wpływów czeskich (por. cz. bohabojný) - trudno powiedzieć. Nie przemawia za tym brak tej formy w południowych gwarach Śląska, z reguły podtrzymujących dawne wpływy czeskie. Śląskie bogabojny należy wiązać z rodzimą modyfikacją, nawiązującą do motywacji 'Boga się bojący'.

Trzeci z wymienionych bliskoznaczników, bogomyślny, mający znaczenie 'zgodny z zasadami wiary, poświęcony Bogu, dotyczący Boga' znany nam jest 
jedynie ze zbiorów Stanisława Wallisa ${ }^{1}$. Badacz w zapisce podaje wprawdzie kontekst użycia (To bót święty clowiek, bo jeny bogomyślne słowa prawiot), ale nie podaje lokalizacji geograficznej. Współcześnie bierna znajomość wyrazu potwierdzona została przez informatora z Bogucic pow. kluczborski. Dotychczas nie stwierdzono obecności leksemu bogomyślny w zasobie leksyki jakiejkolwiek innej polskiej gwary, toteż przypadek śląski jest szczególny. Leksem używany był w dawnej polszczyźnie, XV-XVII wieku, w tekstach stylu wysokiego w znaczeniu ‘zatopiony myślami w Bogu, kontemplacyjny', co potwierdzają starsze i nowsze słowniki [por. np. SłStp i SłDor]. Na Śląsk wyraz przedostał się zapewne wraz z importowaną z Polski literaturą religijną.

W gwarach południowego Śląska i w bezpośrednio z nimi sąsiadujących gwarach Śląska środkowego zwracają uwagę kontynuanty prasłowiańskiego wyrazu *bŕdce 'kołek, żerdka' (będącego zdrobnieniem od *bŕ do [zob. SłPsł I, s. 429]) z oryginalnym rozwojem sonantu w 'er, a więc: bierce, bierco, bierca, por. pol. bardo. Wyraz bierce występuje w znaczeniach 'orczyk' (Zaolzie, pow. cieszyński, bielski, pszczyński, wodzisławski, mikołowski, rybnicki, raciborski, kozielski) ${ }^{2}$ oraz 'drąg służący do dźwigania konewek z wodą; nosidło' (Śląsk Cieszyński), również 'drewniana podpórka zastępująca kalece odjętą nogę, rodzaj protezy' (pow. bielski). Natomiast wyraz bierco pojawia się w znaczeniu 'orczyk' (Zaolzie, pow. cieszyński, raciborski, rybnicki, kozielski, głubczycki, a nawet na południu pow. opolskiego) oraz w znaczeniu 'drążek do zawieszania ubitej świni' (Śląsk Cieszyński). Forma bierca (niewykluczone, że to lm.) notowana była w pow. raciborskim w znaczeniu 'orczyk'. Z formami śląskimi związane są formalnie, znaczeniowo i geograficznie laskie berce, byrce 'orczyk' [Zaręba, 1969-1996, m. 38]'. Śląskie pochodzenie mają obecne w gwarach żywieckich bierce, bierco 'orczyk', 'drążek do zawieszania ubitej świni', 'kij do cepa' [zob. Nowak, 2012; SGP; Zaręba, 1969-1996, m. 38]. Żywieckie formy z 'er, jako efekt oddziaływania sąsiednich gwar śląskich, są wyjątkami na tle małopolskich form z -ar-, por. barca 'część warsztatu tkackiego', 'nosidło' (pow. myślenicki, żywiecki), barce 'nosidło' (pow. myślenicki) [por. SGP].

Śląski rozwój omawianych form był ograniczony regionalnie, trudno powiedzieć, czy odbywał się przy wsparciu form czeskich bądź morawskich, por. brdce, brdco [SSJC; Bartoš, 1906]. Natomiast wykluczony jest wpływ wschodniosłowiański, zob. ros. dial. бépųe czy ukr. берųé [SłPsł I, s. 429]. Śląskie formy z 'er

Stanisław Wallis (1895-1957) badacz folkloru i kultury Śląska.

2 W gwarach środkowego Śląska ta część wozu konnego nazywana jest zwykle orczykiem, natomiast na Śląsku północnym - barczykiem.

3 W tym odsyłaczu cyfra oznacza numer mapy. 
utrzymały się do dzisiaj mimo obecności grupy ar w wyrazach etymologicznie pokrewnych, por. bardla, bardo (< psł. *brddo) i synonimicznych barczek, barczyk.

Z podstawą bierać (psł. *birati) będącą iteratywną formą od brać ${ }^{4}$ (psł. *bbrati) łączy się czasownik bierkować w znaczeniu 'wyrabiać ciasto na chleb; formować bochenki chleba'. Czasownik oznacza więc tę fazę wypieku, w której wybiera się ciasto z dzieży, dodaje wody lub mąki, miesza się ciasto, aby uzyskać właściwą konsystencję, formuje bochenki. Leksem notowany jest tylko w gwarach środkowego i północnego Śląska, ma też dość bogatą dokumentację tekstowa, por.: napszót czeba te ciasto biyrkowac ${ }^{5}$ (Bełk, pow. rybnicki); musa chlyb biyrkować (Kalety-Jędrysek, pow. tarnogórski); ciasto jus porusone tera musa biyrkować chlyp (Lisów, pow. lubliniecki); naudż mie chlyb biyrkować (Ortowice, pow. kędzierzyńsko-kozielski); biyrkuje sie na pecynki (Żędowice, pow. strzelecki); psziniyjź mi z góry ty sómiónki, bo zarołz bana(m) biyrkować (Januszkowice, pow. krapkowicki); Jag zajś pszidzie ciasto do góry (porusy sie), to tsza biyrkować. Nasuje sie mónki na biyrkownica(m), dot sie ciasta tela, co tsza na jedyn pecynek, a potyń tulakać, a na sómiónka(m) (Stara Schodnia, pow. opolski) [Gołąb, 1955, s. 151]; biyrkuje sie tyn chlyp (Dzierżysławice, pow. prudnicki) [Pluta, 1973]. Czasownik używany jest też w znaczeniu przenośnym 'bić kogoś' [Pluta, 1973]; pełna dokumentacja [zob. SGŚ]. Od czasownika bierkować powstały nazwy stolnicy: bierkownica (spośród synonimów leksem ten ma najszerszy zasięg geograficzny, notowany był w gwarach środkowego Śląska i północnośląskich gwarach opolskich), bierkownia (pow. tarnogórski), bierkowaczka (gwary niemodlińskie i prudnickie), bierkownik (pow. prudnicki). Wszystkie te formy notowane są wyłącznie w gwarach śląskich.

Skoro jesteśmy przy formacjach pochodnych od czasownika brać, bierać, to dla dopełnienia obrazu derywacji odnotować należy kolejne śląskie dialektyzmy semantyczne, mianowicie: bierka, bierny, bierus.

Leksem bierka jest szeroko rozpowszechniony w gwarach polskich, z wyjątkiem gwar śląskich, jako nazwa różnych przedmiotów i części warsztatu tkackiego. Natomiast na Śląsku pojawił się jako hapax legomenon w znaczeniu ogólnopolskiej branki, tj. w znaczeniu 'pobór wojskowy', do tego wyłącznie w zapisach historycznych, por. Tego roku będzie wielka bierka (Śląsk Cieszyński) [Cinciała]; bez lokalizacji odnotowuje wyraz rękopiśmienny Słownik Michała Przywary z przełomu XIX i XX wieku [vol. 3, s. 17; vol. 4, s. 21, 318, 350]. Współczesnych poświadczeń nie mamy. Warto w tym miejscu wspomnieć, że

4 Brać (psł. *bbrati) czasownik o szerokim spektrum znaczeniowym w dialektach, m.in. 'nabierać, pobierać, kłaść, umieszczać, wsadzać' [por. SGP].

Cytaty podaję w zapisie uproszczonym. 
wymieniana w słownikach homonimiczna bierka 'gatunek owcy o krótkiej wełnie' też 'młoda owca' to właściwie forma fonetyczna od birka [co do etymologii zob. SłPsł I, s. 477].

Dwa kolejne leksemy, tj. bierny, bierus, mają podobną semantykę, w obu przypadkach nieodnotowaną w słownikach polszczyzny ogólnej i gwarowej. Bierny oznacza 'człowieka chciwego, lubiącego garnąć rzeczy i pieniądze ku sobie, chciwego' i pojawia się w gwarach oleskich i kluczborskich. Zaś bierus to 'naciaggacz, zdzierca; człowiek, często ksiądz, który żąda więcej pieniędzy niż się należy' z odcieniem pogardliwym. Wyraz ma notowanie historyczne z terenu Śląska Cieszyńskiego, współcześnie z okolic Raciborza.

Ciekawymi etymologicznie dialektyzmami śląskimi są: beresić, bereśnik, bereśniczka. Intrygująca jest już forma fonetyczna, sugerująca wschodniosłowiańskie korzenie leksemów. Czasownik beresić zanotowany został w dwóch znaczeniach: 1) 'pośredniczyć w zawieraniu małżeństwa, swatać': Lubliniec, Kochanowice pow. lubliniecki (por. zapis bereźnig beresi dziołcha kawalyrowi); 2) 'strofować, udzielać nagany, karcić': Zabrze, Tarnowskie Góry - Pniowiec (por. zapis rechtór beresiot synka), Krzyżowa Dolina pow. opolski (por. óna beresióła sfoja małol dziólcha, bo psziszła w mokrych trzewikach ze szkoły). Biorąc pod uwagę rozpiętość znaczeń, mamy tu zapewne do czynienia z homonimami, przy czym nie jest wykluczone, że beresić2 'strofować, ganić' jest pożyczką z niem. brechen. W dalszym ciagu interesuje nas beresićl 'swatać', który to czasownik leży u podstaw derywatów bereśnik 'mężczyzna pośredniczący w zawarciu małżeństwa' (Lubliniec, Kochanowice pow. lubliniecki, zob. wyżej, Broniec pow. oleski) oraz bereśniczka 'kobieta pośrednicząca w zawarciu małżeństwa, swatka' (Broniec pow. oleski). Zatem żywotność wyrazów potwierdzona jest współcześnie z gwar środkowo-wschodniego Śląska ${ }^{6}$.

Poza Śląskiem leksem bereśnik zapisany został dwukrotnie: 1) w znaczeniu 'swat' w okolicach Ostrowa Wielkopolskiego [Zaręba, 1969-1996, m. 735; SGP], co w świetle rozpowszechnionych w gwarach południowej Wielkopolski form swat, faktor, sugeruje śląską pożyczkę, a jednocześnie szerszy pierwotnie zasięg wyrazu bereśnik na Śląskuㄱ; 2) jako homonim bereśnik ${ }^{2}$ w znaczeniu 'drobny handlarz nierogacizny' w okolicach Tarnowa [SGP]. We współczesnej polszczyźnie ogólnej mamy tylko zbereźnik 'hultaj, bezwstydnik' [SłDor; USP] i zbereźny 'bezwstydny, haniebny' (wyraz odnotowuje Narodowy Korpus Języka Polskiego). W Słowniku... Jana Karłowicza, Adama Kryńskiego i Władysława

6 Co ważne, nie odnotowuje ich obecności na tym terenie Atlas językowy Ślaska, zob. [Zaręba, 1969-1996, m. 735].

7 Wg danych Zaręby [1969-1996, m. 735] północny Śląsk nie zna pojęć swat, swatka. 
Niedźwiedzkiego odnotowano leksem beresić 'dokazywać, psocić' oraz berezyje, bereźnik, które autorzy odsyłają do odpowiedników z przedrostkiem z-: zberezyje 'figle, psoty', zbereźnik 'psotnik, figlarz', zbereżeństwo 'sprośność, bezeceństwo' [SW], ten ostatni wyraz w znaczeniu 'figiel, psota' odnotowuje [SWil]. Inne leksykony interesujących nas leksemów nie potwierdzają. Wydaje się, że formy beresić, bereśnik, bereśniczka były od początku dialektyzmami i nie zadomowiły się w polszczyźnie literackiej, co sugeruje Aleksander Brückner [1985, s. 647]. Wg niego wyrazy tworzące tę rodzinę pojawiły się w polszczyźnie w XVI-XVII wieku jako metaforyczna nazwa 'beztroskiej zabawy, hultajstwa, nierządu' pochodząca od nazwy geograficznej Pobereże 'kraina historyczna na Podolu' (por. psł. *bergъ); cyt. jak na pobereżu, mawiano o 'nierządzie' [Brückner, 1985, s. 647]. Wyrazy te przedostały się do polszczyzny śląskiej i jako archaizmy peryferyjne utrzymały się do czasów współczesnych.

Już analiza kilkunastu śląskich leksemów gwarowych pokazuje wielość i złożoność procesów rozwojowych, jakim podlegała leksyka tego regionu. Odnotowujemy tu archaizmy (betknać, betknyć), formalny i semantyczny rozwój regionalizmów (betkocić, bierkownica i synonimy bierka, bierny, bierus, branka, bogabojny), odziaływanie sąsiednich gwar małopolskich na gwary śląskie i odwrotnie (bierce, bierco), zapożyczenia z polszczyzny i ich swoisty rozwój (bogomyślny, beresić, bereśnik, bereśniczka). Wyniki tych analiz należy potraktować jako przesłankę przemawiającą za koniecznością podjęcia głębszych studiów etymologicznych nad leksyką polskich gwar Śląska.

\section{ROZWIAZZANIA SKRÓTÓW}

SGP - Słownik gwar polskich, oprac. przez Zakład Dialektologii Polskiej Instytutu Języka Polskiego Polskiej Akademii Nauk w Krakowie, t. 1-2: Mieczysław Karaś, red., t. 3-5: Jerzy Reichan, red., Wrocław - Kraków 1979-1998; t. 6-7: Joanna Okoniowa, red. Kraków 2001-2013.

SGŚ - Słownik gwar śląskich, 2000-2012, t. 1-13, pod red. B. Wyderki, Opole.

SSJC - Slovník spisovného jazyka českého, 1989, t. 1-8, pod red. B. Havránka, Praha.

SłDor - Słownik języka polskiego, 1958-1969, t. 1-11, pod red. W. Doroszewskiego, Warszawa.

SłPsł - Słownik prasłowiański, 1974-2001, t. 1-8, pod red. F. Sławskiego, Wrocław - Warszawa - Kraków - Gdańsk. 
SłStp - Słownik staropolski, 1953-2001, t. 1-11, Wrocław - Warszawa - Kraków - Gdańsk.

SW - Słownik języka polskiego, 1900-1927, t. 1-8, pod red. J. Karłowicza, A. Kryńskiego i W. Niedźwiedzkiego, Warszawa.

SWil - Słownik języka polskiego, 1861, t. 1-2, oprac. A. Zdanowicz i in., Wilno.

USP - Uniwersalny słownik języka polskiego, 2003, t. 1-4, pod red. S. Dubisza, Warszawa.

\section{Skróty konwencjonalne}

$\begin{array}{ll}\text { cyt. - cytat } & \text { perf. - perfectum } \\ \text { cz. - czeski } & \text { pol. - polski } \\ \text { dial. - dialektalny } & \text { pow. - powiat } \\ \mathrm{lm} . \quad \text { - liczba mnoga } & \text { psł. - prasłowiański } \\ \text { m. - mapa } & \text { ros. - rosyjski } \\ \text { niem. - niemiecki } & \text { ukr. - ukraiński }\end{array}$

BIBLIOGRAFIA

BAŃKowski Andrzej, 2000, Etymologiczny słownik języka polskiego, t. 1-2, Warszawa.

BARTOŠ František, 1906, Dialektický slovník moravský, Praha.

BRÜCKNER Aleksander, 1985, Słownik etymologiczny języka polskiego. Przedruk z wyd. 1, Warszawa.

CinciaŁa Andrzej, 1998, Słownik dialektyczny Księstwa Cieszyńskiego. Reprodukcja techniką offsetową z oryginału znajdującego się w zbiorach rękopisów Biblioteki Polskiej Akademii Nauk w Krakowie, Wisła.

GoŁĄB Piotr, 1955, Gwara Schodni i okolicy, Wrocław.

LINDE Samuel Bogumił, 1807-1814, Słownik języka polskiego, t. 1-4, Warszawa.

NowaK Józef Karol, 2012, Słownik gwary górali żywieckich, Żywiec - Grojec - Warszawa.

Pluta Feliks, 1973, Słownictwo Dzierżysławic w powiecie prudnickim, Wrocław. PRzYwara Michał, Narzecza śląskie, vol. 3. Słownik, vol. 4. Materiały do słownika, rkp. Biblioteki Śląskiej w Katowicach nr R 15/II.

ZaręBA Alfred, 1969-1996, Atlas językowy Śląska, t. 1-8, Warszawa - Kraków. 